\title{
Attack Behavior of Podisus rostralis (Heteroptera: Pentatomidade) Adults on Caterpillars of Bombyx mori (Lepidoptera: Bombycidae)
}

\author{
Walkymário Paulo Lemos ${ }^{1,2}$, José Cola Zanuncio ${ }^{2}$ and José Eduardo Serrão ${ }^{3}$ \\ ${ }^{1}$ Laboratório de Entomologia; Embrapa Amazônia Oriental; C. P. 048; 66095-100; wplemos@ cpatu.embrapa.br; \\ Belém - PA - Brasil. ${ }^{2}$ Departamento de Biologia Animal; Universidade Federal de Viçosa; 36571-000; \\ zanuncio@ufv.br; Viçosa - MG - Brasil. ${ }^{3}$ Departamento de Biologia Geral; Universidade Federal de Viçosa; \\ 36571-000; jeserrao@ufv.br; Viçosa-MG-Brasil
}

\begin{abstract}
Attack behavior of the predator Podisus rostralis (Stäl) (Heteroptera: Pentatomidae) adults on fourth instar Bombyx mori L. (Lepidoptera: Bombycidae) caterpillars was studied in laboratory conditions. Ten 24 hours old adults of this predator were observed during two hours with the following attack behavior: (1) Predator: prey finding; prey observation; touching prey with antenna; attack behavior; prey paralysis; predator retreat after attack; attack cessation; successive attacks; and (2) Prey: defense. The predator P. rostralis found its prey before attacking and it approached it with slow circular movements. The attack was usually made in the posterior part of the prey to reduce defense reaction. Larger size of prey in relation to the predator resulted difficult prey paralysis but it occurred in less than two hours.
\end{abstract}

Key words: Asopinae, alternative prey, biological control, ethology, insecta

\section{INTRODUCTION}

Pest control with natural enemies has been increasing due to environmental, economical, social and ecological problems with insecticides (Zanuncio et al., 1994) and Heteroptera predators are important agents of biological control (MolinaRugama et al., 1997; Lemos et al., 2003). Predation is a complex process and it is necessary to identify factors affecting it such as prey and predator densities, prey (defense mechanisms) and predator characteristics (attack mechanisms) (Holling, 1959). Predatory stinkbugs can persist in the field even during periods of prey shortage (Molina-Rugama et al., 1998) what increases their importance for biological control in agricultural and forest areas (Santos et al., 1996; MolinaRugama et al., 1997; Mohaghegh et al., 1999; Medeiros et al., 2000; Lemos et al., 2001 and 2003). Podisus are general predators that feed on Lepidoptera (Lemos et al., 2001 and 2003), Coleoptera (Biever and Chauvin, 1992; HoughGoldstein and McPherson, 1996), Homoptera, Orthoptera and Diptera (Molina-Rugama et al., 1997 and 1998).

Podisus rostralis (Stäl) (Heteroptera, Pentatomidae) is found in most countries of South America (Thomas, 1992), but unlike other predatory Pentatomidae (Molina-Rugama et al., 1997; Zanuncio et al., 2000 and 2001; Medeiros et al., 2000; Lemos et al., 2001 and 2003) few studies

\footnotetext{
* Author for correspondence
} 
have been developed with this species. The development of immature of $P$. rostralis with three alternative preys (Matos Neto et al., 1999) and reproductive strategy of its females with different feeding intervals (Molina-Rugama et al., 1998) were studied in laboratory. In Brazil, $P$. rostralis was collected associated with defoliator caterpillars in an eucalyptus plantation and it was considered as a promising biological control agent in these environments (Molina-Rugama et al., 1998).

The type of prey can affect the performance of predatory bugs (Stamp et al., 1991; Lemos et al., 2003) in laboratory and field conditions. It is important to study predation process between the predatory stinkbug $P$. rostralis and preys such as Bombyx mori L. (Lepidoptera: Bombycidae) during the predation process because these insects generally select prey based on their defense capacity (Marston et al., 1978) and nutritional quality (Lemos et al., 2003). B. mori is considered a nutritional adequate prey for predators in laboratory (Zanuncio et al., 1993) but its large size may hinder predation process by possible increasing defense reactions.

Initial studies have been developed on behavior of predatory bugs (Carvalho et al., 1995) but no research has been done on attack pattern of $P$. rostralis on alternative prey. Thus, the purpose of this work was to study attack behavior of $P$. rostralis adults on $B$. mori caterpillars.

\section{MATERIALS AND METHODS}

Specimens of $P$. rostralis were obtained from a mass rearing unit of the laboratory of Biological Control of Insects, "Instituto de Biotecnologia Aplicada à Agropecuária - BIOAGRO”, Federal University of Viçosa (UFV), State of Minas Gerais, Brazil and the prey B. mori was obtained from a mass rearing unit of the Department of Animal Biology of the UFV. Twenty specimens of fifth instar nymphs of $P$. rostralis were placed individually in Petri dishes $(9.0 \mathrm{~cm} \varnothing \times 1.5 \mathrm{~cm}$ height) with a moisten cotton ball and daily fed with one Tenebrio molitor L. (Coleoptera: Tenebrionidae) pupa until adult stage.

Ten $P$. rostralis adults, as used in other behavior studies with Heteroptera predators (Torres et al., 1997), were placed individual in Petri dishes (14.5 $\mathrm{cm} \varnothing \mathrm{x} 1.5 \mathrm{~cm}$ height) with a moisten cotton ball and starved during $24 \mathrm{~h}$. After this period, they received one fourth instar $B$. mori in the center of each Petri dish and the cotton ball was removed. Attack behavior of this predator and prey defense were registered with uninterrupted direct observation during two hours and each adult predator represented one replication.

Terms and definitions used to describe attack behavior of $P$. rostralis and prey defense were: (1) Predator- (a) prey finding- the predator finds its prey and present fast movements at all directions with antennas; (b) prey observation- the predator observes its prey with its antennas pointed forward and, in general, with short movements; (c) Touching prey with antennas- light touching prey with antennas, usually before the attack; (d) Attack behavior- insertion of stylets into prey body; (e) Immediate attack- normally it occurs three minutes after finding the prey; (f) Prey paralysisimmobilization of prey after insertion its stylets; (g) Retreat of predator after attack - the predator retreats after strong defensive movements of the prey; (h) Cessation of attack- the predator does not continue to attack after prey reaction; (i) successive attacks- attacks at short intervals of time. (2) Prey- (a) defense- abrupt movements of the body to avoid the predator.

\section{RESULTS}

P. rostralis made fast movements with antennas, which indicated that it was searching the prey, followed by antenna and rostrum cleaning with fast and repeated foreleg movements. This behavior was repeated many times before finding the prey because caterpillars of $B$. mori were always walking inside Petri dishes. If prey started moving direction to the predator, it ( $P$. rostralis) immediately changed its direction as an escape behavior. This behavior seemed to be frequent after the predator found its prey.

$P$. rostralis increased movements of antennas in all directions after finding the prey. Antennas were immediately turned up which showed a perception of scents followed by an immobile observation of prey with antennas pointed forward (Fig. 1). Predator began to move and to approximate slowly in circles around the prey in attacking position what was represented by antennas pointed forward in a V-shape and the rostrum extended (Figs. 2 and 3). However, if the prey made any abrupt movements or it pointed its head during this 
approach the predator retreated, but soon after it made another approach and attack.

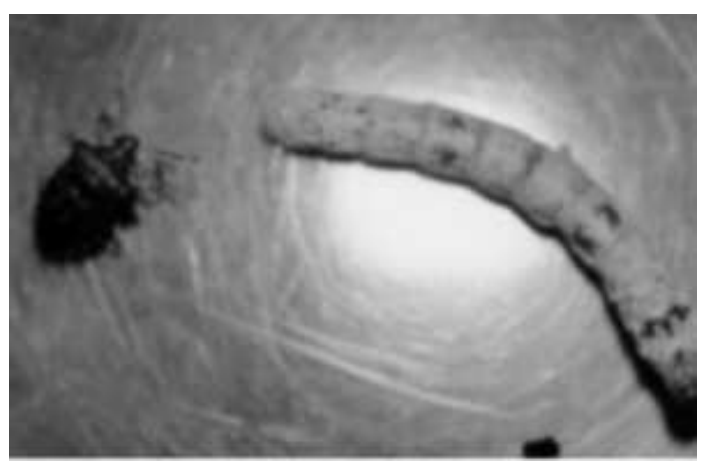

Figure 1 - The predator Podisus rostralis (Heteroptera: Pentatomidae) observing an immobile caterpillar of Bombyx mori (Lepidoptera: Bombycidae) with antenna forward before attack.

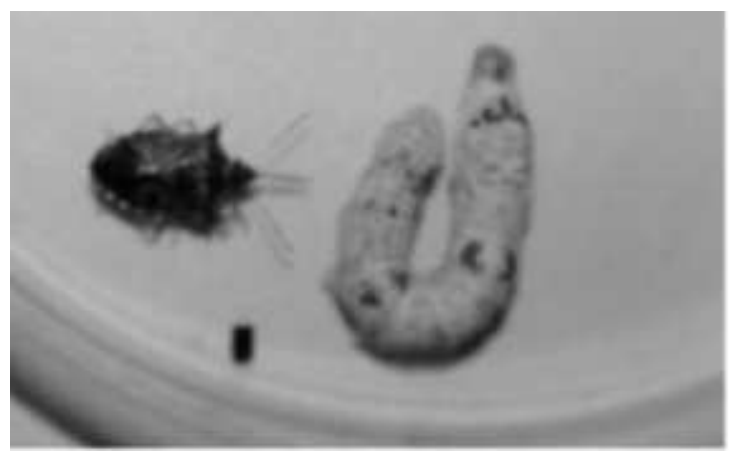

Figure 2 - The predator Podisus rostralis (Heteroptera: Pentatomidae) in attack position and antenna forward in $\mathrm{V}$-shape and rostrum extended.

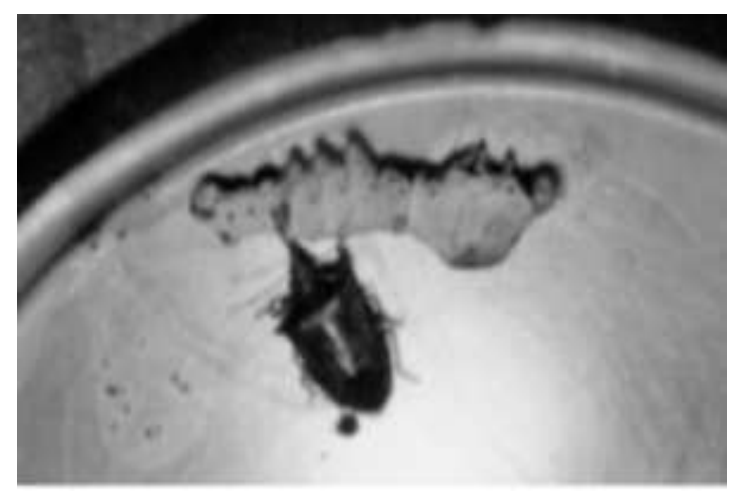

Figure 3 - The predator Podisus rostralis (Heteroptera: Pentatomidae) attacking the prey Bombyx mori (Lepidoptera: Bombycidae).
Most $P$. rostralis attacks were made in the posterior part of prey body although some individuals attacked, without success, the head area of B. mori. When stylets were inserting into prey body (first attack), the prey reacted with violent body movements with its head pointed to the predator. Prey sometimes escaped from predator attack (Fig. 4).

$P$. rostralis could give up attacking; but if caterpillars of $B$. mori retreated a new attack attempt was immediately made or the predator stayed immobile observing the prey for some minutes while moving its antennas (Fig. 1). After this, individuals of $P$. rostralis started slow circular movements around the prey with its antennas pointed forward and its rostrum extended with another approach and new attack (second attack). However, if the prey made any movement with its head pointed to the predator, it retreated but a new attack attempt (third attack) was made soon. Period between first and second attack attempts lasted from one to 30 minutes with an average of 13 minutes.

$P$. rostralis continued with its stylets inserted into prey body while ingesting prey fluid and with its antennas in the horizontal position in relation to its head (Fig. 3) even if prey was not completely paralyzed.

B. mori usually presented an efficient defense against $P$. rostralis after the second attack, with strong movement of the body to escape predation. Predator could give up attack or it could make successive attacks with approach and attack behaviour. Predator paralyzed $80 \%$ of prey in two hours (Fig. 4). If prey defecated, the predator assumed attack position (antennas forward and rostrum extended) followed by inserting its stylets into the feces. Ethogram with stages of attacking behaviour of $P$. rostralis on $B$. mori caterpillars is presented in Fig. 4.

\section{DISCUSSION}

$P$. rostralis alternated fast movements with periods of immobility, which was similar with that observed for P. nigrispinus (Carvalho et al., 1995), but without a behaviour with defined stages. $P$. rostralis significantly increased movements of antennas after finding the prey which was a typical attacking behavior of predatory Heteroptera (Cohen, 1995; Zanuncio et al., 2000). 
Prey finding

ע(10)

(04)

Antennal movements

Aproximating prey with antenna

forward and rostrum extended

(04)

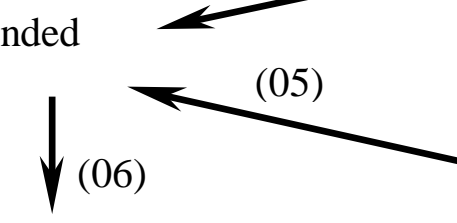

Touching prey with antenna

(06)

Immediate attack $\left(1^{\text {st }}\right) \quad$ Attacking prey $\left(1^{\text {st }}\right)$

$\Downarrow(04)$

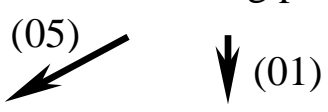

Posterior part of prey $\quad$ Middle part of prey

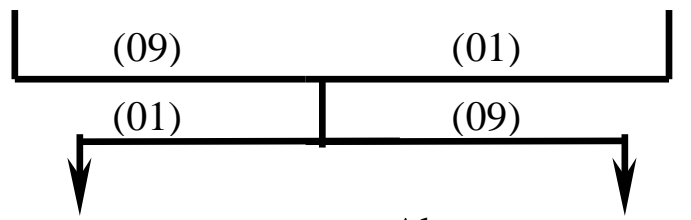

Prey paralysis

Abrupt movement of prey escaping

from predator

v (09)

Predator immobile observing prey

Circular movements around

prey
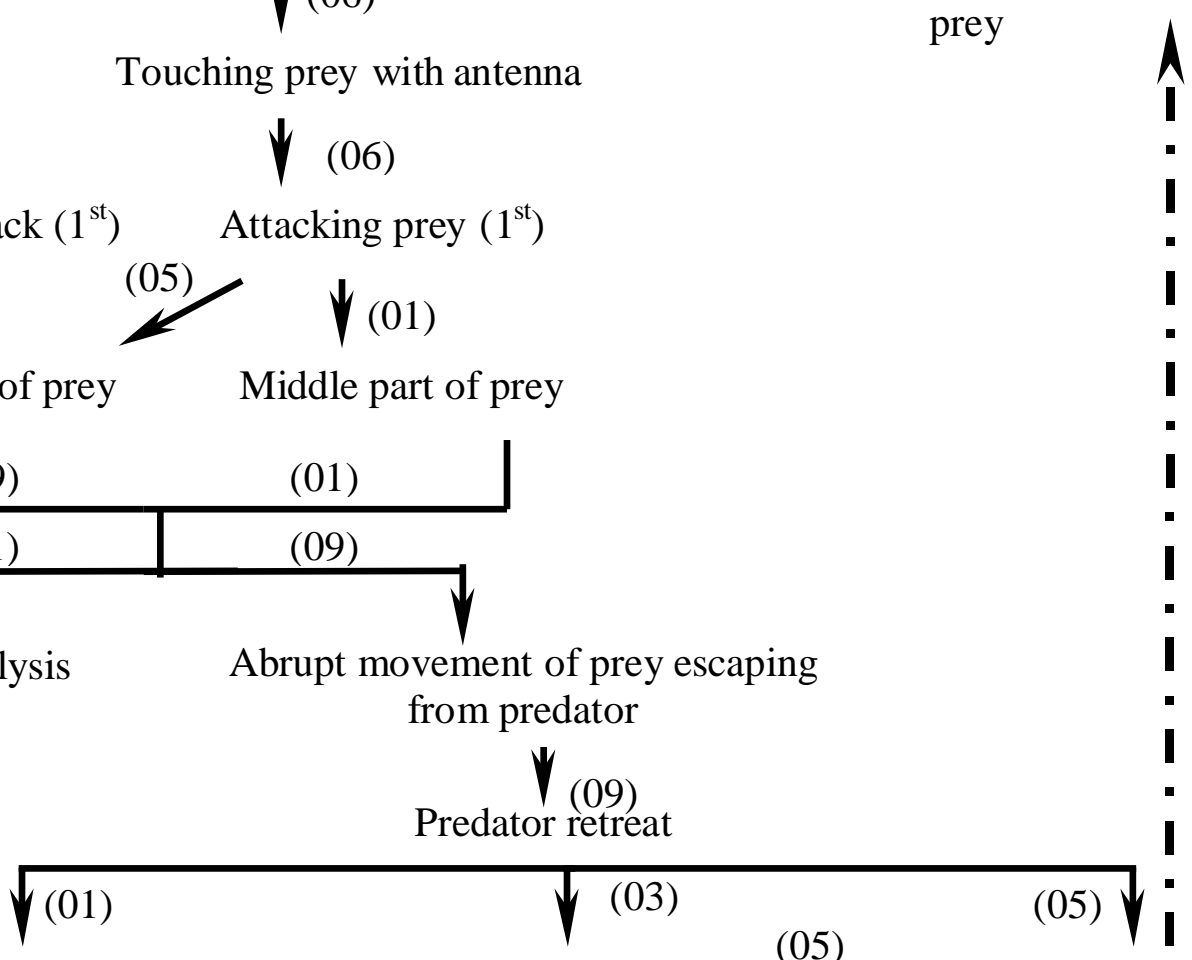

Giving up attack

New attack attempt<smiles>CCCO</smiles>

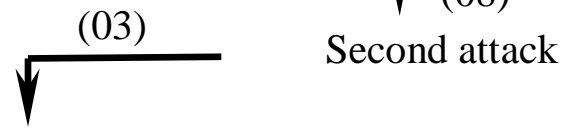

$(05)$

Prey paralysis

Abrupt prey movement avoid predator

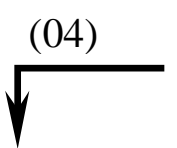

Successive attacks<smiles>CC(C)(C)[GeH3]</smiles>

Predador retreat

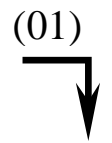

Give up attack

Figure 4 - Sequence of attack behavior of the predator Podisus rostralis (Heteroptera: Pentatomidae) with frequency of insects per stage of each behavioural sequence during two hours. 
These predators can use visual, chemical or tactile cues to locate and recognize their prey and the first is the most important sense used (De Clercq, 2000). P. rostralis preferred to attack the posterior part of prey body perhaps because this part was more distant from the head and, therefore, with less defensive response or because this area was softer which facilitated insertion of its stylets. Also $P$. rostralis prefers to attack immobile caterpillars what suggests that it avoids spending energy fighting preys. However, it is necessary to the predator to approach its prey because Asopinae bugs generally react to prey movements up to a distance of $10 \mathrm{~cm}$. Detection of immobile preys seems to occur with antenna or rostrum contacts (De Clercq, 2000).

High reaction power of $B$. mori caterpillars may be due to its large size compared to other alternative prey for P. rostralis such as T. molitor and Musca domestica L. (Diptera: Muscidae) which are commonly used in laboratory to rear predatory Pentatomidae. This suggests that prey size can be an efficient defense mechanism against predators compared to that observed for $S$. cincticeps with $T$. molitor (Azevedo and Ramalho, 1999) and $M$. domestica (Zanuncio et al., 1995).

Besides, prey behavior affects the ability of pentatomid predators to find and subdue them (De Clercq, 2000).

Approximately $79 \%$ of species of predatory arthropods use pre-oral digestion to feed on large prey (Cohen, 1995). Rate of food ingestion for Podisus maculiventris (Say) (Heteroptera: Pentatomidae) was constant regardless of prey type, because feeding process was affected by internal pressure of the prey during the first part of feeding period and predator maintained its suction with capillarity by pharynx pump action (Gallopín and Kitching, 1972). Therefore, a similar feature may occur with $P$. rostralis.

Prey show different responses to attack by predators. They may escape thrashing, biting, regurgitating or even injuring or killing stinkbugs (De Clercq, 2000). Hyphantria cunea Drury (Lepidoptera: Arctiidae) caterpillars made violent movements with the head and the thorax and sometimes pressed legs and/or antennas of the predator $P$. maculiventris with its mandibles (Morris, 1963). Fourth instar caterpillars of Malacosoma californicum pluviale (Dyar) (Lepidoptera: Lasiocampidae) did not escape from repeated attacks by $P$. maculiventris even with active movements but fifth instar larvae of this insect avoided predator attack (Iwao and Wellington, 1970). Caterpillars of Anticarsia gemmatalis Hübner (Lepidoptera: Noctuidae) and Plathypena scabra Fabricius (Lepidoptera: Noctuidae) escaped with fast body movements before $P$. maculiventris could insert its stylets (Marston et al., 1978). Caterpillars of Heliothis zea (Boddie) (Lepidoptera: Noctuidae) showed aggressive behavior after attack by predators and frequently avoided insertion of their stylets.

Caterpillars of Trichoplusia ni (Huebner) (Lepidoptera: Noctuidae) and Pseudoplusia includens Walker (Lepidoptera: Noctuidae) are more frequently attacked by predators because they are less aggressive (Marston et al., 1978). Caterpillars of Helicoverpa punctigera (Wallengren) (Lepidoptera: Noctuidae) avoid capture by Oechalia schellenbergii (GuérinMéneville) (Heteroptera: Pentatomidae) by rotating their head and abdomen (Awan, 1985). This was also observed for $B$. mori what suggested that fourth instar caterpillars of this prey have efficient defense mechanism against attack by $P$. rostralis because only one predator paralyzed its prey immediately after the first attack.

Some individuals of $P$. rostralis were unable to paralyze its prey after two hours even with successive attacks. This suggested that this species was a timid predator like other Asopinae bugs (De Clercq, 2000). This was also observed for adults of $P$. nigrispinus with a longer time to attack than its nymphs but with $50 \%$ of them paralyzing prey in less than one hour (Saavedra et al., 1997). De Clercq (2000) also reported that these bugs might take several minutes to an hour approaching preys after finding and orientating to them.

$P$. rostralis maintained its antenna in horizontal position in relation to its head during feeding which was also observed for Geocoris punctipes (Say) (Hemiptera: Lygaeidae) (Cohen, 1995). This predator attacked prey feces showing that it could use, beside visual cues, odor to find prey in the field which was also observed for $P$. maculiventris (Pfannenstiel et al., 1995). Several asopines can also use airborne chemical to detect prey (De Clercq, 2000).

Our results corroborated the potential of $P$. rostralis for biological control of defoliator caterpillars and it demonstrated possibilities of rearing this natural enemy with caterpillars of $B$. mori in spite of defensive reaction presented by this prey during attack of this predator. 


\section{ACKNOWLEDGEMENTS}

We express our appreciation to Conselho Nacional de Desenvolvimento Científico e Tecnológico (CNPq), Coordenação de Aperfeiçoamento de Pessoal de Nível Superior (CAPES), and to Fundação de Amparo à Pesquisa do Estado de Minas Gerais (FAPEMIG) for the financial support.

\section{RESUMO}

Estudou-se, em laboratório, o comportamento de ataque de adultos do predador Podisus rostralis (Stäl) (Heteroptera: Pentatomidae) tendo como presa lagartas de quarto estádio de Bombyx mori L. (Lepidoptera: Bombycidae). Dez adultos do predador, com 24 horas de idade, foram observados durante duas horas acompanhando-se os seguintes comportamentos de ataque: (1) Predador: localização da presa; observação da presa; toque das presas com as antenas; comportamento de ataque; paralisação da presa; fuga do predador após ataque; finalização do ataque; ataques sucessivos; e (2) Presa: defesa. O predador $P$. rostralis localizou sua presa antes do ataque, aproximando-se dela através de lentos movimentos circulares. O ataque é, usualmente, realizado na parte posterior da presa para reduzir reação de defesa. O maior tamanho da presa em relação ao predador pode dificultar a paralisação, porém o predador consegue paralisá-la em menos de duas horas.

\section{REFERENCES}

Awan, M. S. (1985), Anti-predator plays of Heliothis punctigera (Lep: Noctuidae) caterpillar against the predator Oechalia schellenbergii (Hem.: Pentatomidae). Aust. J. Zool., 33, 885-890.

Azevedo, F. R. and Ramalho, F. S. (1999), Impacto da temperatura e da defesa da presa na utilização de Tenebrio molitor L. por ninfas do predador Supputius cincticeps (Heteroptera: Pentatomidae). An. Soc. Entomol. Brasil, 28, 111-119.

Biever, K. D. and Chauvin, R. L. (1992), Suppression of the Colorado potato beetle (Coleoptera: Chrysomelidae) with augmentative releases of predaceous stinkbugs (Hemiptera: Pentatomidae). $J$. Econ. Entomol., 85, 720-726.
Carvalho, R. S.; Vilela, E. F.; Borges, M. and Zanuncio, J. C. (1995), Comportamento de acasalamento do predador Podisus nigrispinus (Dallas), em laboratório. An. Soc. Entomol. Brasil, 24, 165-171.

Cohen, A. C. (1995), Extra-oral digestion in predaceous terrestrial Arthropoda. An. Rev. Entomol., 40, 85-103.

De Clercq, P. (2000), Predaceous stinkbugs (Pentatomidae: Asopinae). In: Schaefer, C. W. and Panizzi, A. R. (Eds.). Heteroptera of Economic Importance. Cambridge: Cambridge University. pp. 737-789.

Gallopín, G. C. and Kitching, R. L. (1972), Studies on the process of ingestion in the predatory bug Podisus maculiventris (Hemiptera: Pentatomidae). Can. Entomol., 104, 231-237.

Holling, C. S. (1959), Some characteristics of simple types of predation and parasitism. Can. Entomol., 91, 385-398.

Hough-Goldstein, J. and McPherson, D. (1996), Comparison of Perillus bioculatus and Podisus maculiventris (Hemiptera: Pentatomidae) as potential control agents of the Colorado potato beetle (Coleoptera: Chrysomelidae). J. Econ. Entomol., 89, 1116-1123.

Iwao, S. and Wellington, W. G. (1970), The influence of behavioral differences among tent-caterpillar larvae on predation by a Pentatomidae bug. Can. J. Zool., 48, 896-898.

Lemos, W. P.; Medeiros, R. S.; Ramalho, F. S. and Zanuncio, J. C. (2001), Effects of plant feeding on the development, survival, and reproduction of Podisus nigrispinus (Dallas) (Heteroptera: Pentatomidae). Int. J. Pest Manag., 27, 89-93.

Lemos, W. P.; Ramalho, F. S.; Serrão, J. E. and Zanuncio, J. C. (2003), Effects of diet on development of Podisus nigrispinus (Dallas) (Het., Pentatomidae), a predator of the cotton leafworm. $J$. Appl. Ent., 127, 389-395.

Marston, N. L.; Schmidt, G. T.; Biever, K. D. and Dickerson, W. A. (1978), Reaction of five species of soybean caterpillars to attack by the predator, Podisus maculiventris. Env. Entomol., 7, 53-56.

Matos Neto, F. C.; Zanuncio, J. C.; Freitas, L. C. and Gomes, B. M. R. (1999), Nymphal development of the predator Podisus rostralis (Heteroptera: Pentatomidae) fed with three alternative prey. Brenesia, 50, 72-77.

Medeiros, R. S.; Ramalho, F. S.; Lemos, W. P. and Zanuncio, J. C. (2000), Age-dependent fecundity and life-fertility tables for Podisus nigrispinus (Dallas) (Het., Pentatomidae). J. Appl. Entomol., 124, 319-324.

Mohaghegh, J.; De Clercq, P. and Tirry, L. (1999), Effects of rearing history and geographical origin on reproduction and body size of the predator Podisus nigrispinus (Heteroptera: Pentatomidae). Eur. J. Entomol., 96, 69-72. 
Molina-Rugama, A. J.; Zanuncio, J. C.; Torres, J. B. and Zanuncio, T. V. (1997), Longevidad y fecundidad de Podisus nigrispinus (Heteroptera: Pentatomidae) alimentado con Musca domestica (Diptera: Muscidae) y frijol. Rev. Biol. Trop., 45, 1125-1130.

Molina-Rugama, A. J.; Zanuncio, J. C.; Zanuncio, T. V. and Oliveira, M. L. R. (1998), Reproductive strategy of Podisus rostralis (Stal) (Heteroptera: Pentatomidae) females under different feeding intervals. Bioc. Sci. Technol., 8, 583-588.

Morris, R. F. (1963), The effect of predator age and prey defence on functional response of Podisus maculiventris (Say) to the density of Hypantria curnea Drury. Can. Entomol., 95, 1009-1020.

Pfannenstiel, R. S.; Hunt, R. E. and Yeargan, K. V. (1995), Orientation of a hemipteran predator to vibrations produced by feeding caterpillars. J. Ins. Behav., 8, 1-9.

Saavedra, J. L. D.; Zanuncio, J. C.; Zanuncio, T. V. and Guedes, R. N. C. (1997), Prey capture ability of Podisus nigrispinus (Dallas) (Het., Pentatomidae) reared for successive generations on a meridic diet. $J$. Appl. Entomol., 121, 327-330.

Santos, T. M.; Silva, E. N. and Ramalho, F. S. (1996), Consumo alimentar e desenvolvimento de Podisus nigrispinus (Dallas) sobre Alabama argillacea (Huebner) em condições de laboratório. Pesq. Agrop. Bras., 31, 699-707.

Santos, T. M.; Silva, E. N. and Ramalho, F. S. (1996), Consumo alimentar e desenvolvimento de Podisus nigrispinus (Dallas) sobre Alabama argillacea (Huebner) em condições de laboratório. Pesq. Agrop. Bras., 31, 699-707.

Stamp, N. E.; Erskine, T. and Paradise, C. J. (1991), Effects of rutin-fed caterpillars on an invertebrate predator. Oecologia, 88, 289-295.

Thomas, D. B. (1992), Taxonomic synopsis of the Asopinae Pentatomidae (Heteroptera) of the western hemisphere. Lanham: Entomological Society of America. $156 \mathrm{pp}$.

Torres, J. B.; Zanuncio, J. C. and Oliveira, M. C. (1997), Mating frequency and its effect on female reproductive output in the stinkbug predator Podisus nigrispinus (Heteroptera: Pentatomidae). Med. Fac. Landbouww. Univ. Gent, 62/2b, 491-498.

Zanuncio, J. C.; Leite, J. E. M.; Alves, J. B. and Santos, G. P. (1993), Duração do período ninfal e sobrevivência do predador Podisus connexivus Bergroth (Hemiptera, Pentatomidae), em três presas alternativas. Rev. Bras. Zool., 10, 327-332.

Zanuncio, J. C.; Nascimento, E. C.; Garcia, J. F. and Zanuncio, T. V. (1994), Major lepidopterous defoliators of eucalypt, in the Southeast Brazil. For. Ecol. Manage., 65, 53-63.
Zanuncio, J. C.; Zanuncio, T. V.; Guedes, R. N. C. and Ramalho, F.S. (2000), Effect of feeding on three Eucalyptus species on the development of Brontocoris tabidus (Het.: Pentatomidae) fed with Tenebrio molitor (Col.: Tenebrionidae). Bioc. Sci. Tech., 10, 443-451.

Zanuncio, J. C.; Molina-Rugama, A. J.; Serrão, J. E. and Pratissoli, D. (2001), Nymphal development and reproduction of Podisus nigrispinus (Heteroptera: Pentatomidae) fed with combinations of Tenebrio molitor (Coleoptera: Tenebrionidae) pupae and Musca domestica (Diptera: Muscidae) larvae. Bioc. Sci. Tech., 11, 331-337.

Zanuncio, T. V.; Zanuncio, J. C.; Vilela, E. F. and Santos, G. P. (1995), Biologia de Supputius cincticeps Stal (Hemiptera: Pentatomidae) criado em larvas de Tenebrio molitor (Coleoptera: Tenebrionidae) e de Musca domestica (Diptera: Muscidae). Rev. Bras. Ent., 39, 183-187.

Received: March 29, 2004; Revised: October 19, 2004; Accepted: August 03, 2005. 